\section{Directory of British Health Resorts}

THE British Health Resorts Association, Tavistock Square, W.C.1, has just published its official Handbook entitled "British Health Resorts : Spa, Seaside, Inland" (2s. 6d. net). The volume, which is edited by Drs. Fortescue Fox and Wyndham Lloyd, is a guide to the spas and health resorts, seaside and inland, of the British Isles and British Dominions and Colonies, giving particulars of their climate and rainfall, the characteristics of their baths and waters, if any, and indications of the conditions for which they are suitable. The Minister of Health contributes a foreword, and chapters are included on the science of waters and baths and on climates, with maps, charts and many illustrations.

\section{Recent Earthquakes}

Tнв recently enhanced seismic activity has continued. Several strong earthquakes and tremors have been experienced in many widely separated places. On May 6, violent tremors were felt in Chile, especially in the neighbourhood of the epicentre of the destructive shock of January 24. Many buildings damaged previously in Chillan, San Carlos and Parral collapsed, but there was no loss of life. Port of Spain, Trinidad, experienced a severe tremor on the evening of May 7, but no damage was reported and there were no casualties. On the morning of May 8, a severe tremor occurred in the neighbourhood of Athens but again no damage is reported. The strongest shock, however, was on the morning of May 8. Provisional readings of the initial pulses ( $P$ waves) of seismograms and calculated epicentral distances are as follows: Kew, $1 \mathrm{~h} .51 \mathrm{~m} .48 \mathrm{~s}$. (compressional), $\triangle$, nearly $23^{\circ}$; Paris, $1 \mathrm{~h} .51 \mathrm{~m} .55 \mathrm{~s}$. , $\triangle, 2,540 \mathrm{~km}$. ; Uccle, 1h. $52 \mathrm{~m}$. $11 \mathrm{~s}$. (compressional), $\triangle, 2,700 \mathrm{~km}$.; Hamburg, 1h. 52m. 50s., $\triangle$, $3,100 \mathrm{~km}$.; De Bilt, 1h. $52 \mathrm{~m}$. $21 \mathrm{~s} ., \triangle$, about $24 \cdot 5^{\circ}$. The shock was also recorded at West Bromwich, and at Selfridges in London the maximum double amplitude was nearly $6^{\prime \prime}$. These readings point to an epicentre in the Azores at approximately latitude $37^{\circ} \mathrm{N}$., longitude $24^{\circ} \mathrm{W}$., with normal depth of focus, and initial time approximately $1 \mathrm{~h} .46 \mathrm{~m}$. 50s. G.C.T. Reports from Ponta Delgada state that at about this time a severe earth tremor lasting about twenty-five seconds was experienced on Sao Miguel Island in the Azores but no damage was caused. The shock was preceded by unusual heat and terrifying underground rumblings. It is known that a definite band of epicentres lies near the Dolphin or North Atlantic Divide on which the Azores are situated, although earthquakes are not so numerous on this band as in the Mediterranean or circum-Pacific regions of instability.

\section{Physical Society's Rutherford Memorial Lecture}

IT is right and fitting that we should, in due season, praise the work of famous men, and no man has left the impress of his work and personality more deeply graven on the structure of modern physical science than has Ernest Rutherford. It has been said with truth that he was on the crest of the wave of scientific advance; it has been said, with deeper truth, that he made the wave. A memorial lecture is a useful and appropriate form of homage, which has been adopted by the Physical Society, it was announced at the summer meeting of the Society held at University College, Southampton, on June 9. The Society's Rutherford Memorial Lecture is to be given annually between October and March, and to be devoted to an address on some topic concerning recent advances in atomic and nuclear physics. The first lecture will be given in the session 1939-40.

\section{International Congress of Biology}

THE first International Congress of Biology will be held at Brussels on July 9-12 under the presidency of Prof. E. Spehl. Discussions have been arranged on the role of diet in the output of muscular work, introduced by M. Bigwood; physiology of muscular contraction (M. Bouckaert); muscular work and circulation of the blood (M. Heymans); physiological mechanisms during training (M. Brouha). Further information can be obtained from the secretariat, 96 Avenue Paul Janson, Anderlecht, Brussels.

\section{Physics of Metals}

The University of Pittsburgh, Pennsylvania, is organizing a summer course during July 6-August 11 on the "Physics of Metals", which will deal with the fundamental structure of metals and other solids. An attempt will be made to understand the nature of the forces which make pure metals and alloys hard or soft, ductile or brittle, good or bad conductors of electricity, etc. The lecturers include: Dr. John C. Slater, head of the Department of Physics, Massachusetts Institute of Technology; Dr. M. F. Manning, University of Pittsburgh ; Dr. W. Shockley, Bell Telephone Laboratories; Dr. Frederick Seitz, University of Pennsylvania ; and Dr. E. U. Condon, associate director, Westinghouse Research Laboratory. Further particulars can be obtained from Prof. E. Hutchisson, University of Pittsburgh.

\section{French Association for the Advancement of Science}

A PROVISIONAx programme and a list of sectional presidents (twenty-two in number) have now been issued for the Liège meeting on July 17-22 of the French Association for the Advancement of Science. Arising out of the formation at Cambridge of the new Division for the Social and International Relations of Science of the British Association, an exchange of views between the British and French Associations was arranged, as a result of which it was decided to elect to honorary membership of the Association the president, vice-president, secretary, deputy-secretary, treasurer and secretary of council of the French Association. The latter has now elected to honorary membership the president (Sir Albert Seward), general treasurer (Prof. P. G. H. Boswell), general secretaries (Profs. F. T. Brooks and A. Ferguson) and secretary (Dr. O. J. R. Howarth) of the British Association. The offices of the French Association are at rue Serpernte 28, Paris VIe. 